\title{
Performance of the Production Characteristics of the Reciprocal Crosses of Native Chicken of Kerala and N Strain (IWN) of White Leghorn
}

\author{
S. Harikrishnan*, Binoj Chacko, P. Anitha, Beena C. Jospeh, \\ K. Anilkumar and Joseph Mathew
}

College of Veterinary and Animal Sciences, Mannuthy, Kerala Veterinary and Animal Sciences University, India

*Corresponding author

Keywords

Crossbreds,

Backyard, Egg

quality, Haugh unit

Article Info

Accepted:

12 November 2019

Available Online:

10 December 2019

\section{A B S T R A C T}

A study was conducted at All India Co-ordinated Research Project (AICRP) on Poultry for Eggs, Mannuthy centre, Kerala, to evaluate the production characteristics of the reciprocal crosses of native chicken of Kerala with $\mathrm{N}$ strain (IWN) of White Leghorn. Based on the results of crossbreds, significantly $(\mathrm{p}<0.05)$ higher number of eggs with early sexual maturity was observed for the progeny of the birds with IWN as sire and native chicken as dam (ND 1) than its reciprocal cross (DN 1). The performance of the crossbreds with respect to egg weight, livability and egg quality traits (shell thickness and yolk colour score) were comparable. The major egg shell colour observed for both the crossbreds was tinted followed by white and brown. Haugh unit score was found better for ND 1 birds. Based on the results, it can be concluded that ND 1 birds were superior to DN 1 birds in case of production traits. However, field trials have to be conducted to confirm the present results under backyard conditions.

\section{Introduction}

Cross breeding helps in attaining productivity enhancement for native chicken in a much faster pace. In this method, the advantageous genes of native germplasm are being exploited along with the exotic genes to achieve the desired hybrid vigour. White Leghorn ' $N$ ' strain (IWN) capable of producing 300 eggs/year (AICRP 2018-19), is being maintained at All India Co-ordinated Research Project (AICRP) on Poultry for Eggs, Mannuthy centre. But these birds are not well suited for backyard poultry rearing. Therefore, by crossing IWN strain maintained at AICRP with native chicken of Kerala may result in a promising crossbred chicken suitable for backyard purpose with an expected production 
potential of 200 eggs per annum with good tropical adaptability. Therefore, the present study was conceived to assess the production performance of the reciprocal crosses of native chicken $\mathrm{x}$ IWN chicken.

\section{Materials and Methods}

Reciprocal crosses were made between unselected population of native chicken of Kerala and improved White Leghorn N strain (IWN strain which was selected for egg number for 29 generations) maintained at AICRP, Mannuthy centre. IWN strain of $29^{\text {th }}$ generation kept as sire crossed with unselected native chicken as dam was given the name ND 1. The unselected native chicken kept as sire crossed with IWN strain of $29^{\text {th }}$ generation as dam was given the name DN 1. Hundred birds of each cross were housed in individual cages at the end of 16 weeks of age and production traits viz., egg production, age at sexual maturity, egg weight, egg quality traits and per cent livability were recorded till 40 weeks of age. The significance of difference of means of the traits was determined by Z-test as per Snedecor and Cochran (1994).

\section{Results and Discussion}

\section{Egg production}

Results of hen housed egg production (HHN) revealed that ND 1 birds produced 120.99 eggs while DN 1 birds had 110.97 eggs during 17-40 weeks of age (Table 1). Overall egg production in ND 1 birds was significantly $(\mathrm{p}<0.01)$ higher than that of DN 1 birds. i.e, when genetically improved White Leghorn birds were used as sire with native birds as dam. Similar results were observed when improved PB 2 (sire) was crossed with local chicken of Punjab (dam), where the progeny produced more eggs compared to the progeny of its reciprocal cross (55.37 vs 48.90 eggs) (AICRP, 2016-17). Crawford (1990) reported that differences in hen housed egg production for such reciprocal crosses are substantial and varies within 0-19 per cent. In the present study, the variation in hen housed egg percentage between the reciprocal crosses was 5.70 per cent and the results are in the range reported by the author.

Compared to the present findings, higher egg number (124.75 eggs) was reported for the cross between White Nicobari and White Leghorn by Ahlawat et al., (2002). White leghorn X native birds of Gujarath and Naked neck X White Leghorn had lower hen housed egg production of 92.72 and 86.39 eggs, respectively (AICRP 2017-18; John 2000). Still lower eggs of 64 and 56 eggs, respectively were reported for Yamuna (Kadaknath x White Leghorn) and Aseel X White Leghorn (Mallik et al., 2002; Prafulla 2012).

\section{Age at sexual maturity}

The value for age at sexual maturity was significantly $(\mathrm{p}<0.001)$ lower for ND 1 birds $(139.46 \pm 1.19)$ than DN $1(146.58 \pm 0.94)$. The lowered age at sexual maturity which was a desired trait in poultry, might have resulted in the significantly higher egg production in ND 1 birds than DN 1 . The early age at sexual maturity shown by the crosses between native chicken and IWN in the present study compared to other crossbreds involving native germplasm reported in the literature (John, 2000; Ahlawat and Padhi, 2001; Singh, 2001; Choudhary et al., 2002; Mallik et al., 2002; Prafulla, 2012; AICRP, 2016-17; AICRP, 2017-18) may be due to crossing of native birds with long term selected IWN.

\section{Egg weight}

ND 1 chicken had a mean egg weight of $44.29 \pm 0.30 \mathrm{~g}$ while DN 1 had $44.55 \pm 0.28 \mathrm{~g}$ at 28 weeks of age. The egg weight was 
$48.08 \pm 0.38$ and $48.96 \pm 0.39 \mathrm{~g}$, respectively in the above crossbreds at 40 weeks of age. The mean egg weight between both the crossbreds was statistically comparable at 28 and 40 weeks of age. The egg weight values obtained at 28 weeks of age for the crosses between native chicken of Kerala and IWN is comparable with the results of cross between native chicken of Gujarath $\mathrm{x}$ WL (AICRP, 2016-17) and Aseel X WL (Prafulla, 2012). Higher egg weight was observed for Nacked neck X WL (John, 2000) and for Yamuna (Kadaknath x WL) breed (Mallik et al., 2002) at 28 weeks of age.

At 40 weeks of age, the crossbreds viz., Nacked neck X WL (John, 2000), WL X Black Nicobari (Ahlawat and Padhi, 2001), Kadaknath x WL (Mallik et al., 2002) and Dahlem Red X native chicken of Himachal Pradesh (AICRP, 2016-17) showed higher egg weight than the present cross under study; while WL X native chicken of Gujarath
(AICRP, 2016-17) showed lower egg weight of $44.43 \mathrm{~g}$. The results of egg weight of WL X native chicken of Kerala at 40 weeks of age are comparable with the results of Black Nicobari X WL (Ahlawat and Padhi, 2001).

\section{Egg qualiy traits}

The major egg shell colour observed for both ND 1 and DN 1 crossbreds was tinted followed by white and brown (Table 2). It was also noticed that the proportion of brown and tinted colour eggs is getting reduced as age advances to 40 weeks of age in both ND and DN crossbreds. This may be considered as a disadvantage in backyard rearing since brown eggs from the household rearing fetches premium price in the market. Tinted egg shell colour was reported by John (2000) and Prafulla (2012) in their studies involving White Leghorn crossed with Nacked neck and Aseel, respectively.

Table.1 Period-wise hen housed egg number (HHN) of ND 1 and DN 1 chicken from 17 to 40 weeks of age

\begin{tabular}{|c|c|c|c|}
\hline \multirow{2}{*}{ Period } & \multirow{2}{*}{ Age in weeks } & \multicolumn{2}{|c|}{ HHN $($ Mean \pm SE $)$} \\
\cline { 3 - 4 } & & ND 1 & DN 1 \\
\hline I & $17-20$ & $4.06^{\mathrm{a}} \pm 0.49$ & $1.23^{\mathbf{b}} \pm 0.28$ \\
\hline II & $21-24$ & $23.25^{\mathrm{a}} \pm 0.61$ & $19.84^{\mathrm{b}} \pm 1.29$ \\
\hline III & $25-28$ & $24.53 \pm 0.46$ & $23.69 \pm 0.50$ \\
\hline IV & $29-32$ & $23.92 \pm 0.48$ & $23.17 \pm 0.42$ \\
\hline V & $33-36$ & $23.25 \pm 0.57$ & $22.77 \pm 0.36$ \\
\hline VI & $37-40$ & $21.98 \pm 0.69$ & $20.27 \pm 0.72$ \\
\hline Total & $\mathbf{1 7 - 4 0}$ & $\mathbf{1 2 0 . 9 9}^{\mathbf{a}} \pm \mathbf{2 . 2 3}$ & $\mathbf{1 1 0 . 9 7}^{\mathbf{b}} \pm \mathbf{2 . 1 8}$ \\
\hline
\end{tabular}

Table.2 Phenotypic frequency of egg shell colour of ND 1 and DN 1 chicken, per cent

\begin{tabular}{|c|c|c|c|c|c|c|}
\hline \multirow{2}{*}{$\begin{array}{c}\text { Age } \\
\text { (in weeks) }\end{array}$} & \multicolumn{2}{|c|}{ Brown } & \multicolumn{2}{c|}{ Tinted } & \multicolumn{2}{c|}{ White } \\
\hline & ND 1 & DN 1 & ND 1 & DN 1 & ND 1 & DN 1 \\
\hline $\mathbf{2 8}$ & 24.47 & 29.47 & 45.74 & 63.16 & 29.79 & 7.37 \\
\hline $\mathbf{4 0}$ & 22.83 & 15.73 & 39.13 & 59.55 & 38.04 & 24.72 \\
\hline
\end{tabular}


Mean egg shell thickness recorded for both the reciprocal crossbreds (ND 1 and DN 1) were statistically comparable and in the range $0.34 \pm 0.01$ to $0.36 \pm 0.01 \mathrm{~mm}$ at 28 weeks and $0.39 \pm 0.01$ for both the crossbreds at 40 weeks of age. The results of the present study were in agreement with the reports of John (2000) for Nacked neck $X$ White Leghorn birds. However, lower egg shell thickness was reported for Kadaknath X Brown Cornish, Aseel X Brown Cornish, Kadaknath X RIR, Aseel X RIR, Nicorock and Nishibari (Gupta et al., 2007; Choudhuri et al., 2014).

The yolk colour score determined for the eggs of ND 1 and DN 1 were statistically comparable and in the range $7.33 \pm 0.23$ to $7.47 \pm 0.26$ at 28 weeks and $7.00 \pm 0.17$ to $7.10 \pm 0.15$ at 40 weeks. The yolk colour score of the crossbreds under study were comparable with the findings of Prasoon (2013) for the eggs of the progenies of Australorp crossed with various strains (F, N and P) of White Leghorn.

The Haugh unit score of eggs in ND 1 $(80.99 \pm 2.58)$ was significantly $(p<0.05)$ better than and DN $1(68.10 \pm 4.16)$ at 40 weeks while the Haugh unit between the crossbred was comparable $(78.85 \pm 4.37$ to $80.08 \pm 2.42)$ at 28 weeks of age. The results of the Haugh Unit score of ND 1 was comparable with the findings of John (2000) who reported a score of 84.78 for Naked neck x White Leghorn birds while lower Haugh Unit score was observed for DN 1 birds.

\section{Livability}

The data on livability during the entire period of study showed that both the crosses have performed well (96\% in ND1 and 99\% in DN $1)$.

The overall livability range observed for the crosses in the present study agrees with the reports of John (2000), Mallik et al., (2002) and Prafulla (2012) for the crossbreds such as Naked neck X White Leghorn, Kadaknath X White Leghorn (Yamuna) and Aseel X White Leghorn. Good livability in the crossbreds is an ideal trait to perform better in backyard system of rearing. However, a lower livability (88.75\%) was reported for White Leghorn X native chicken of Gujarath (AICRP, 2016-17). From the study, it was observed that ND 1 birds (IWN strain of $29^{\text {th }}$ generation kept as sire crossed with unselected native chicken as dam) were found superior in egg production and age at sexual maturity than DN 1 birds (unselected native chicken kept as sire crossed with IWN strain of $29^{\text {th }}$ generation as dam). The other production traits such as egg weight, egg quality traits (shell thickness and yolk colour) and livability were comparable among the crossbreds. The major egg shell colour observed for both the crossbreds was tinted followed by white and brown.

However, Haugh unit score was found better for ND 1 birds. Based on the results, it can be concluded that ND 1 birds was superior to DN 1 birds in the case of production traits. However, field trials have to be conducted to confirm the present results under backyard conditions.

\section{Acknowledgement}

The author sincerely acknowledges the Dean, College of Veterinary and Animal Sciences, Mannuthy and also Kerala Veterinary and Animal Sciences University for all the financial help as well as facilities provided for the research work.

\section{References}

Ahlawat, S.P.S., Sunder, J., Padhi, M.K., Kundu, A., Chatterjee, R.N., Saha, S.K., Kumar, S.J., Yadav, S.P. and Rai, R.B. 2002. Comparative 
performance of various crosses of Nicobari fowl with White Leghron [abstract]. In: Proceedings of the National Workshop on Characterization and Conservation of Indigenous Poultry Germplasm; $26^{\text {th }}$ to $27^{\text {th }}$ February, 2002. National Agricultural Technology Project, Division of Animal Science and Andaman Science Association, Central Agricultural Research Institute, Port Blair. p.78.

Ahlawat, S.P.S. and Padhi, M.K. 2001. Performance of Nicobari fowl in harsh environmental of $\mathrm{A}$ and $\mathrm{N}$ islands. In: Proceedings of the National Seminar on appropriate poultry for adverse environment, Hyderabad. pp 101-107.

AICRP [All India Co-ordinated Research Project]. 2016-17. Annual report of poultry breeding and seed project. ICAR, Directorate of Poultry Research, 94p.

AICRP [All India Co-ordinated Research Project]. 2017-18. Annual report of poultry breeding and seed project. ICAR, Directorate of Poultry Research, 106p.

AICRP [All India Co-ordinated Research Project]. 2018-19. Annual report of All India Co-ordinated Research Project on Poultry Improvement. Mannuthy centre, Kerala Veterinary and Animal Sciences University, 16p.

Choudhuri, R.S., Vaishnav, J.K. and Gahlot, G.C. 2002. Performance of improved indigenous germ plasm in arid zone. In: Dr. R.N. Chatterjee (ed.), Proceedings of the National Workshop on Characterization and Conservation of Indigenous Poultry Germplasm; $26^{\text {th }}$ to $27^{\text {th }}$ February, 2002. National Agricultural Technology Project, Division of Animal Science and Andaman Science Association, Central Agricultural Research Institute, Port
Blair. pp. 135-137.

Choudhuri, N.C., Paul, G, Kundu, A., Kundu M,S., De A,K. and Ram N. 2014. Evaluation of egg quality traits of endangered Nicobari fowl and its crosses under intensive and backyard system of Andaman and Nicobar islands, India. Vet. Wld. 7: 693-697.

Crawford, R. D. 1990. Quantitative genetics and selection. In: Poultry Breeding and Genetics. $\left({ }^{\text {st }}\right.$ Ed.). Elsevier Science Pubishers, Netherlands, pp. 599-984.

Gupta, C.S., Kumar, A., Arya, R., Patel, M., Ghosh, A.K. and Palod, J. 2007. Evaluation of egg quality of crossbred chickens reared under backyard farming in Tarai areas of Uttaranchal. Indian J. Ani. Res. 41: 216 - 219.

John, J. 2000. Performance of crosses of indigenous Naked neck with White Leghorn and New Hampshire. M.V.Sc. thesis, Kerala Agricultural University, Thrissur, Kerala, 107p.

Mallik, B.K., Bangar, N.P. and Ahmad, M. 2002. Conservation of Indian desi fowl Kadaknath and performance study of "Yamuna." In: Dr. R.N. Chatterjee (ed.), Proceedings of the National Workshop on Characterization and Conservation of Indigenous Poultry Germplasm; $26^{\text {th }}$ to $27^{\text {th }}$ February, 2002. National Agricultural Technology Project, Division of Animal Science and Andaman Science Association, Central Agricultural Research Institute, Port Blair. pp. 7376.

Prafulla, M.M. 2012. Comparative study of egg production traits in Aseel $\mathrm{x}$ White Leghorn and Australorp $\mathrm{x}$ White Leghorn cross bred layers. M.V.Sc. thesis, Kerala Veterinary and Animal Sciences University, Pookode, Wayanad, Kerala, 80p.

Prasoon, S. 2013. Performance of progenies of Australorp with F, N and P strains of 
White Leghorn. M.V.Sc. thesis, Kerala Veterinary and Animal Sciences University, Pookode, Wayanad, Kerala, 69p.

Singh, D.P. 2001. Performance of the reciprocal crosses of Aseel x Dahlem red chicken. Proceedings of the
National Seminar on appropriate poultry for adverse environment, Hyderabad. pp. 90-100.

Snedecor, G.W. and Cochran, W.G. 1994. Statistical Methods. ( $8^{\text {th }}$ Ed.), Affiliated East- West Press Pvt. Ltd, New Delhi, India. 313 p.

\section{How to cite this article:}

Harikrishnan, S., Binoj Chacko, P. Anitha, Beena C. Jospeh, K. Anilkumar and Joseph Mathew. 2019. Performance of the Production Characteristics of the Reciprocal Crosses of Native Chicken of Kerala and N Strain (IWN) of White Leghorn. Int.J.Curr.Microbiol.App.Sci. 8(12): 1562-1567. doi: https://doi.org/10.20546/ijcmas.2019.812.187 